\title{
Shape Analysis of Blade AndNumber of Blade for Water Turbine Prototype Performance
}

\author{
Ahmad Yani , Yano Hurung Anoi, Ratnawati, Irianto, Junaini
}

\begin{abstract}
Water turbine is one which the fluid mover works is the water used directly to spin the turbine runner. This study was conducted using pelton type water turbine installation and measurement of the force, rotation and the flow rate by variation of the blade shape. The method used is an experimental method to design a laboratory-scale experiments as well as outputs a water turbine design is used as a practicum student majoring in mechanical engineering. The results showed the influence of the blade shape and the blade number of the water turbine prototype performance:

1. The maximum tangential velocity occurs of a bowlblade shape with blade number 14 with a value of $12.769 \mathrm{rad}$ / s.

2. Hydraulic power value in this study 2.64 Watt and nkinetic power use values in this study 3,886 Watt.

3. The maximum turbine power occurs of a bowlblade shape and blade number 14 with rated power turbine 112262 Watt.

4. Electric generator maximum power occurs of a bowlblade shape and blade number 14 with a value of electric power generator for 1,942 Watt.

5. The maximum turbine efficiency occurs of a bowlblade shape and blade number 14 with a value of turbine efficiency $28.888 \%$. The efficiency of the electric generator maximum occurs of a bowlblade shape and blade number 14, with the value of the electric generator $0.736 \%$.
\end{abstract}

Index Terms - Analysis, blade shape, number of blades, performance, and water turbines.

\section{INTRODUCTION}

Water turbine is one which the fluid mover works is the water used directly to rotate the turbine wheel. At the wheel of the turbine blade and there is a working fluid flows through the space between the blades. [1]

Pelton turbine is an impulse turbine, the turbine is driven by the kinetic energy of water. High bercecepatan spray water on the blade and after moving the water runner out at low speeds, which means most of the energy is not absorbed by the runner. The water pressure in and out of the blade is at atmospheric pressure. [2]

Laboratory is the place to train students in the skills practice, demonstrations, experiments, research and development of science.The existence of the laboratory as a lab is needed to improve the skills of students. Implementation of practical

Ahmad Yani, SekolahTinggiTeknologiIndustriBontang (STTIB),

Bontang, Indonesia.

Yano HurungAnoi, STTIB, Bontang, Indonesia.

Ratnawati, STTIB,Bontang, Indonesia

Irianto, STTIB, Bontang, Indonesia.

Junaini, STTIB, Bontang, Indonesia. activities performed in providing learning experiences to students, so that students can interact with materials materials and direct observation of symptoms that occur on the water turbine test equipment. Practice at the laboratory can improve students' skills when used efficiently, because of the practice students can understand the subjects that require concrete appreciation by doing concrete activities through practice. [3]

Water turbine research conducted by the authors 2016 on kinetic water turbine performance vertical shaft. Similar research conducted by the author year of 2017 with a variety of shapes blade against the torque and power of water turbines and turbine nozzle diameter variation with a turbine wheel braking method. This advanced research by modifying the water turbine designed by previous authors with different methods of research in previously so as to explain how the performance of the prototype turbine pelton water that has been modified when using a variation of blade shape and the number of turbine blades. The shape of the turbine blade and determine the number of turbine rotation so as to improve the performance of the turbine.

\section{LITERATURE}

Water turbine is a machine that converts the driving potential energy into mechanical energy with water as the working fluid. Historically now comes from the hydraulic turbine of the mill - water mill in the medieval era were used to break up the coal, grain mill purposes, and others. [4]. Based on changes in water turbine energy is divided into two groups: impulse turbines and reaction turbines.

\section{A. Impulse Turbine}

Impulse turbine, also known as water turbines same pressure as the water pressure coming out of the nozzle the pressure equal to the surrounding atmospheric pressure. So the energy of the place and the pressure energy possessed by the water flow velocity changed everything into energy. An example of this is the impulse turbine pelton turbine which is a type of turbine is made the object of research the author.[6]

Pelton water turbine is a ring-shaped tool built on the river that has water discharge is small but has a high head. This tool rotates on its axis for their encouragement rapid flow of water through the pipe fast enough. In line with the turning of the turbine, this tool simultaneously take water from the river and collected in a tank, then through a tube passing through a rapid and issued the nozzle.[6]

\section{B. Reaction Turbine}

Reaction turbines are turbines that utilize all the energy (potential energy, kinetic and pressure) to generate kinetic 
energy in the blade. The turbine blade has a special profile reaction that causes a decrease in water pressure during through the blade. This pressure difference forces on the blade so that the runner (turbine rotating parts) can rotate. Turbine working on this principle are grouped as a reaction turbine. Reaction turbine runner fully immersed in water and are in a turbine house.

In testing the water turbine is getting the results expected performance of the turbine. [5]

The calculation process to obtain the performance of the turbine by using the following equation:

\section{Broad cross-section of the tip of the nozzle (A)}

The equation to calculate the area of the nozzle tip of a turbine blade striking the equation / formula 1 :

$$
A=\frac{1}{4} \cdot \pi \cdot d^{2}
$$

With:

$A=$ Area of the nozzle tip $\left(\mathrm{m}^{2}\right)$.

$\mathrm{D}=$ diameter of the nozzle $(\mathrm{m})$

\section{The flow capacity $(Q)$}

To calculate the flow capacity, use the equation 2 :

$$
Q=A \cdot V
$$

With:

$Q=$ Water flow rate $\left(\mathrm{m}^{3} / \mathrm{s}\right)$. $\mathrm{A}=$ Area of the nozzle tip $\left(\mathrm{m}^{2}\right)$.

$v$ = The flow velocity $(\mathrm{m} / \mathrm{s})$.

\section{The flow velocity $(\mathrm{V})$}

To calculate the flow rate, use the equation 3 :

$$
V=\frac{Q}{A}
$$

With:

$$
v \text { = The flow velocity }(\mathrm{m} / \mathrm{s}) \text {. }
$$

$Q=$ Water flow rate $\left(\mathrm{m}^{3} / \mathrm{s}\right)$. $A=$ Area of the nozzle tip $\left(\mathrm{m}^{2}\right)$.

4. The rate of Mass Air Flow ( $)^{\dot{m}}$

To calculate the mass flow used equation 4 :

$$
\dot{m}=\rho . Q
$$

With:

$\dot{m}=$ Water mass flow rate $(\mathrm{kg} / \mathrm{s})$

$\mathrm{P}=$ Density of water $(\mathrm{kg} / \mathrm{m} 3)$.

$Q=$ Water flow rate $\left(\mathrm{m}^{3} / \mathrm{s}\right)$.

5. Angular velocity ( $\omega)$

To get the value of angular velocity using equation 5:

$$
\omega=\frac{2 \pi n}{60}
$$

With:

$$
\begin{aligned}
\omega & =\text { Angular velocity }(\mathrm{rad} / \mathrm{s}) \\
\mathrm{n} & =\text { Round turbine }(\mathrm{rpm})
\end{aligned}
$$

6. Calculate the Power:

a, Hydraulic power; $\mathrm{Ph}$ (Watt) is the power that goes into the nozzle, the magnitude of the amount can be measured by the equation 6 as follows:

$P h=\rho . g Q H$

Where:

$P h=$ Hydraulic power (Watts)

$\mathrm{P}=$ The density of water $996.74(\mathrm{~kg} / \mathrm{m} 3)$.

$\mathrm{g}=$ the gravitational force of the earth, $9.81(\mathrm{~m} / \mathrm{s} 2)$.

$Q=$ Water flow rate $(\mathrm{m} 3 / \mathrm{s})$.
$\mathrm{H}=$ head turbine $(\mathrm{m})$

b. Kinetic power of water jets; $\mathrm{Pk}$ (Watt) is calculated using equation 7:

$\mathrm{P}_{k}=\frac{1}{2} \cdot \rho \cdot A \cdot v^{3}$

With:

$\mathrm{P}_{\mathrm{k}}=$ The kinetic water (Watt).

$\mathrm{P}=$ The density of water $996.74(\mathrm{~kg} / \mathrm{m} 3)$.

$\mathrm{A}=$ cross-sectional area nozzle turbine $(\mathrm{m} 2)$.

$v=$ The flow velocity $(\mathrm{m} / \mathrm{s})$.

c, Turbine power; $\mathrm{Pt}$ (Watt) is calculated by Equation 8:

$P t=P . A . \omega,(\omega-\mathrm{v}) \cdot(1+\cos \theta) \mathrm{x}$

With:

$\mathrm{Pt}=$ Power water turbine (Watt).

$\mathrm{P}=$ The density of water $996.74(\mathrm{~kg} / \mathrm{m} 3)$.

$\mathrm{A}=$ cross-sectional area nozzle turbine $(\mathrm{m} 2)$.

$\omega=$ Angular speed $(\mathrm{rad} / \mathrm{s})$.

$v=$ The flow velocity $(\mathrm{m} / \mathrm{s})$.

$\cos \theta=$

d. Electric Power (Power Generator); Pg (Watt) is calculated by equation 9 :

$P g=V . I \cdot \cos \varphi$

Where:

$\mathrm{Pg}=$ Electrical power (Power Generator); (Watt)

$\mathrm{V}=$ Voltage output electrical generator; (Volt)

$\mathrm{I}=$ Current output electrical generator; (Ampere)

$\cos \varphi=$ Power factor (level)

7. Calculate Efficiency:

a, Turbine blade efficiency; $\eta \mathrm{t}$

$\eta_{t}=\frac{p_{t}}{p_{k}} x 100 \%$

Where:

$\eta \mathrm{t}=$ water turbine efficiency $(\%)$.

$\mathrm{Pt}=$ turbine power (Watts).

$\mathrm{Pk}=$ water kinetic power (Watts).

b. Efficiency generator Turbine; $\eta$ s counted using equation 11:

$$
\eta_{g}=\frac{P_{g}}{P_{h}} x 100 \%
$$

With:

$\eta_{g}=$ Efficiency turbine generator system $(\%)$.

$\mathrm{Pg}=$ power turbine generator (Watt).

$\mathrm{Ph}=$ hydraulic water power (Watts).

\section{METHODS}

Research conducted using experimental methods to design a laboratory-scale experiments using a set up equipment type water turbine pelton impulse as shown in Figure 6 with the test blade shape and the number of turbine blades. Dimensions research tool that is $110 \mathrm{~cm}$ long, $60 \mathrm{~cm}$ wide and $40 \mathrm{~cm}$ high made of steel plate elbow. Water tank size of 60 $\mathrm{cm} \times 60 \mathrm{~cm}$ made of sheet iron plate with a thickness of 0.3 $\mathrm{cm}$. while the size of the turbine runner diameter of $21.5 \mathrm{~cm}$. While the size of the turbine shaft diameter of $2.54 \mathrm{~cm}$ with a length of $80 \mathrm{~cm}$.

\section{A. ResearchVariable}

The variables used in this study, there are three independent variables, the dependent variable and controlled variable. 


\section{Variables}

The independent variable in this study consisted of:

1) Water discharge: $0.0005 \mathrm{~m} 3 / \mathrm{s}$

2) The number of turbine blades 18,16 , and 14 pieces

3) The blade shape is in between: a flat blade, curved blade, the blade half cylinder, blade spoon, and the spoon bowl.

\section{Controlled variables}

1) Conditioned blade angle constant at $90^{\circ}$ position.

2) Turbine nozzle sizes $1 / 2$ inch

\section{Dependent variable}

The dependent variable in this study is the angular velocity, water hydrile power, kinetic power of water, power turbines, power electricity generator, turbine efficiency and the efficiency of the electric generator.

\section{B. Research Procedure}

The testing procedures for data retrieval research is as follows:

1. Create a table to record the test results.

2. Setting up and installing all the installations and their research measuring instruments used.

3. Replacing the nozzle size as determined $1 \frac{1}{2}$ Inch.

4. Installing form a flat blade turbine on the number of blades 18 pieces prior to the first data retrieval.

5. Checking all turbine components are examined to ensure readiness before starting to turn the water pump and make sure that all the conditions of the measuring instrument is in good condition.

6. Press the switch / button to turn on the water pump.

7. Measure the flow rates using a measuring instrument flowmeter, and record the measurement result.

8. Measuring the rotation of the turbine shaft and generator shaft speed with tachometer measuring instrument, and then record the value of rpm on the tachometer measuring instrument.

9. Measuring the output voltage and output current of the generator turbine and record voltage and current values in the meter multitester.

10. Repeat step number four data collection began by installing a curved blade shape, spoon, half-cylinder and blade shape bowls number of blades 16 and 14 until the data retrieval step number five.

11. Process and analyze research data obtained to determine the value of the water turbine performance studied.

12. Draw conclusions from the results of research undertaken.

\section{Installation Research Tools}

In this study, the testing tool used is a water turbine pelton type of horizontal axis design research installation shown in Figure 1.

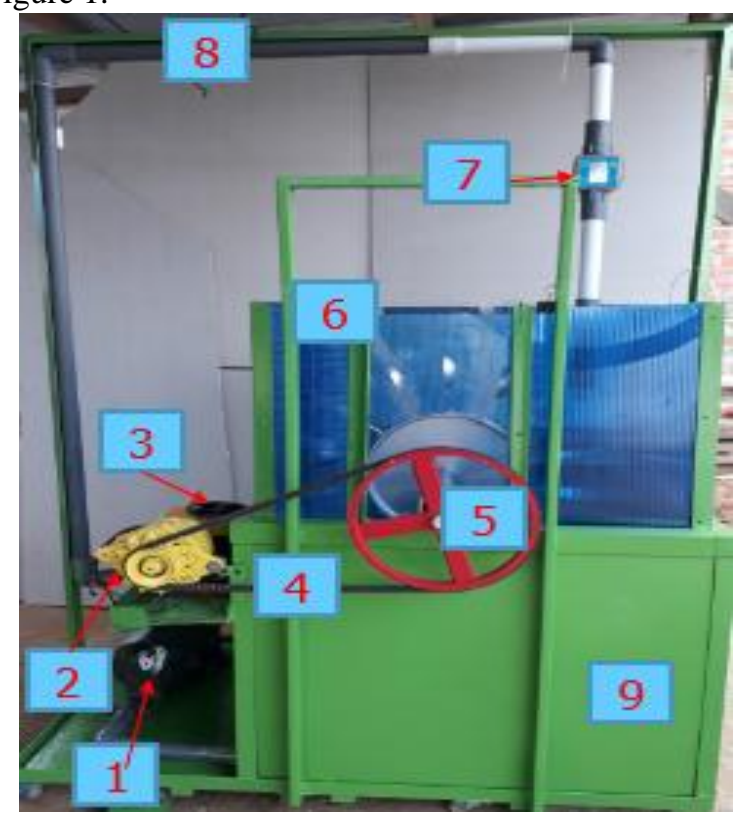

Figure 1. Installation Design Research

Caption water turbine research facility:

1. Water pump

2. Power generator

3. Accu 12 Volt

4. V-belt

5. Pully

6. Turbine installation frame

7. Flowmeter measuring instrument

8. 1-inch PVC pipe

9. Sump Water

\section{RESULTS AND DISCUSSION}

A. Data Results

Research to perform testing of water turbine campus of theBontangIndustrial Technology College. The test is conducted to obtain data turbine rotation, rotation generator, the electrical output voltage, output current of electricity, the turbine head, flow. The research data as shown in Table 1 to Table 5 below:

Table 1. Data testing of forms a flat blade

\begin{tabular}{|c|c|c|c|c|c|c|}
\hline $\begin{array}{c}\text { Num-ber } \\
\text { blades }\end{array}$ & $\begin{array}{c}\text { Genertor } \\
\text { round }\end{array}$ & $\begin{array}{c}\text { Turbines } \\
\text { round }\end{array}$ & $\begin{array}{c}\text { Electri-cal } \\
\text { voltage }\end{array}$ & $\begin{array}{c}\text { Electric } \\
\text { current }\end{array}$ & $\begin{array}{c}\text { Tur-bine } \\
\text { head }\end{array}$ & $\begin{array}{c}\text { Flow } \\
\text { debit }\end{array}$ \\
\hline 18 & 244 & 68 & $0: 42$ & 0012 & $0: 54$ & 0.0005 \\
\hline 16 & 265 & 77 & $0: 35$ & 0012 & $0: 54$ & 0.0005 \\
\hline 14 & 286 & 78 & $0: 43$ & $1: 56$ & $0: 54$ & 0.0005 \\
\hline
\end{tabular}


Table 2. Data testing of curved blade

\begin{tabular}{|l|c|c|c|c|c|c|}
\hline $\begin{array}{c}\text { Num-ber } \\
\text { blades }\end{array}$ & $\begin{array}{c}\text { Genertor } \\
\text { round }\end{array}$ & $\begin{array}{c}\text { Turbines } \\
\text { round }\end{array}$ & $\begin{array}{c}\text { Electri-cal } \\
\text { voltage }\end{array}$ & $\begin{array}{c}\text { Electric } \\
\text { current }\end{array}$ & $\begin{array}{c}\text { Tur-bine } \\
\text { head }\end{array}$ & $\begin{array}{c}\text { Flow } \\
\text { debit }\end{array}$ \\
\hline 18 & 333 & 96 & 2.8 & $0: 14$ & $0: 54$ & 0.0005 \\
\hline 16 & 340 & 93 & 3 & $0: 25$ & $0: 54$ & 0.0005 \\
\hline 14 & 359 & 98 & 3 & $0: 17$ & $0: 54$ & 0.0005 \\
\hline
\end{tabular}

Table 3. Data testing of spoon rice blade

\begin{tabular}{|l|c|c|c|c|c|c|}
\hline $\begin{array}{c}\text { Num-ber } \\
\text { blades }\end{array}$ & $\begin{array}{c}\text { Genertor } \\
\text { round }\end{array}$ & $\begin{array}{c}\text { Turbines } \\
\text { round }\end{array}$ & $\begin{array}{c}\text { Electri-cal } \\
\text { voltage }\end{array}$ & $\begin{array}{c}\text { Electric } \\
\text { current }\end{array}$ & $\begin{array}{c}\text { Tur-bine } \\
\text { head }\end{array}$ & $\begin{array}{c}\text { Flow } \\
\text { debit }\end{array}$ \\
\hline 18 & 307 & 87 & 1.70 & $0: 53$ & $0: 54$ & 0.0005 \\
\hline 16 & 331 & 87 & 1.66 & 0.60 & $0: 54$ & 0.0005 \\
\hline 14 & 337 & 92 & 1.60 & 0.76 & $0: 54$ & 0.0005 \\
\hline
\end{tabular}

Table 4. Data testing of half-cylindrical blade

\begin{tabular}{|c|c|c|c|c|c|c|}
\hline $\begin{array}{c}\text { Num-ber } \\
\text { blades }\end{array}$ & $\begin{array}{c}\text { Genertor } \\
\text { round }\end{array}$ & $\begin{array}{c}\text { Turbines } \\
\text { round }\end{array}$ & $\begin{array}{c}\text { Electri-cal } \\
\text { voltage }\end{array}$ & $\begin{array}{c}\text { Electric } \\
\text { current }\end{array}$ & $\begin{array}{c}\text { Tur-bi } \\
\text { ne head }\end{array}$ & Flow debit \\
\hline 18 & 350 & 93 & 2.98 & $0: 20$ & $0: 54$ & 0.0005 \\
\hline 16 & 342 & 95 & 3.0 & $0: 20$ & $0: 54$ & 0.0005 \\
\hline 14 & 350 & 99 & 2.9 & $0: 19$ & $0: 54$ & 0.0005 \\
\hline
\end{tabular}

Table 5. Data testing ofbowl blade

\begin{tabular}{|l|l|l|l|l|c|c|}
\hline $\begin{array}{c}\text { Num-ber } \\
\text { blades }\end{array}$ & $\begin{array}{c}\text { Genertor } \\
\text { round }\end{array}$ & Turbinesround & $\begin{array}{c}\text { Electri-cal } \\
\text { voltage }\end{array}$ & $\begin{array}{c}\text { Electric } \\
\text { current }\end{array}$ & $\begin{array}{c}\text { Tur-bine } \\
\text { head }\end{array}$ & $\begin{array}{c}\text { Flow } \\
\text { debit }\end{array}$ \\
\hline 18 & 417 & 116 & $3: 42$ & $0: 58$ & $0: 54$ & 0.000 \\
\hline 16 & 420 & 119 & $3: 51$ & 0.61 & $0: 54$ & 0.000 \\
\hline 14 & 439 & 122 & $3: 56$ & 0.62 & $0: 54$ & 0.000 \\
\hline
\end{tabular}

\section{B. .Results of Data Processing}

Data analysis using descriptive technique based on the results of research conducted, data from the field test conducted as in Tables 1 to 5 were then carried out data processing or calculations using formulas applied as listed in the formula 1 to formula to 9 in order to get valuehydraulic power, The kinetic power, the power turbine, electricity generator power, the efficiency of the turbine and generator efficiency as shown in Table 6 to Table 12.

Table 6. Results of data processing tangential velocity

\begin{tabular}{|c|c|c|c|c|c|}
\hline \multirow[t]{2}{*}{ Number of blades } & \multicolumn{5}{|c|}{ Tangential speed, $\omega(\mathrm{rad} / \mathrm{s})$} \\
\hline & Flat blade & Curved blade & $\begin{array}{l}\text { Spoon rice } \\
\text { blade }\end{array}$ & Half cylinders blade & Bowl blade \\
\hline 18 & 7117 & 10048 & 9106 & 9734 & 12141 \\
\hline 16 & 8059 & 9734 & 9106 & 9943 & 12455 \\
\hline 14 & 8164 & 10257 & 9629 & 10362 & 12769 \\
\hline
\end{tabular}

Table 7. Results of data processing hydraulic power

\begin{tabular}{|l|l|l|l|l|c|}
\hline \multirow{2}{*}{ Number of blades } & \multicolumn{4}{|l|}{ Hydraulic power, Ph (Watt) } \\
\cline { 2 - 6 } & Flat blade & Curved blade & $\begin{array}{c}\text { Spoon rice } \\
\text { blade }\end{array}$ & Half cylinders blade & Bowl blade \\
\hline 18 & 2.64 & 2.64 & 2.64 & 2.64 & 2.64 \\
\hline 16 & 2.64 & 2.64 & 2.64 & 2.64 & 2.64 \\
\hline 14 & 2.64 & 2.64 & 2.64 & 2.64 & 2.64 \\
\hline
\end{tabular}


Table 8. Results of the kinetic power of data processing

\begin{tabular}{|c|c|c|c|c|c|}
\hline \multirow[b]{2}{*}{ Number of blades } & \multicolumn{5}{|c|}{ Kinetic power, $\mathrm{Pk}$ (Watt) } \\
\hline & Flat blade & Curved blade & $\begin{array}{l}\text { Spoon rice } \\
\text { blade }\end{array}$ & Half cylinders blade & Bowl blade \\
\hline 18 & 3,886 & 3,886 & 3,886 & 3,886 & 3,886 \\
\hline 16 & 3,886 & 3,886 & 3,886 & 3,886 & 3,886 \\
\hline 14 & 3,886 & 3,886 & 3,886 & 3,886 & 3,886 \\
\hline
\end{tabular}

Table 9. Results of data processing power turbine

\begin{tabular}{|c|c|c|c|c|c|}
\hline \multirow{2}{*}{$\begin{array}{l}\text { Number } \\
\text { blades }\end{array}$} & \multicolumn{5}{|c|}{ Turbine power, $\mathrm{Pt}$ (Watt) } \\
\hline & Flat blade & Curved blade & $\begin{array}{ll}\text { Spoon rice } \\
\text { blade }\end{array}$ & $\begin{array}{ll}\text { Half } & \text { cylinders } \\
\text { blade }\end{array}$ & Bowl blade \\
\hline 18 & 22476 & 61082 & 46806 & 56127 & 99141 \\
\hline 16 & 33018 & 56127 & 46806 & 59409 & 105603 \\
\hline 14 & 34299 & 64495 & 54519 & 66234 & 112262 \\
\hline
\end{tabular}

Table 10. Results of data processing power generator

\begin{tabular}{|l|l|l|c|c|c|}
\hline \multirow{2}{*}{ Number of blades } & \multicolumn{4}{|l|}{ Power generator, Pg (Watt) } & \multicolumn{2}{l|}{ Spoon rice } & Half cylinders blade & Bowl blade \\
\cline { 2 - 6 } & Flat blade & Curved blade & 0793 & 0524 & 1,746 \\
\hline 18 & 0004 & 0345 & 0876 & 0528 & 1884 \\
\hline 16 & 0004 & 0660 & 1,070 & 0485 & 1,942 \\
\hline 14 & 0590 & 0449 & 0 & & \\
\hline
\end{tabular}

Table 11. Results of data processing efficiency of the turbine

\begin{tabular}{|l|l|l|l|l|c|}
\hline \multirow{2}{*}{ Number of blades } & \multicolumn{3}{|l|}{ The efficiency of the turbine, $\eta t(\%)$} \\
\cline { 2 - 6 } & Flat blade & Curved blade & $\begin{array}{c}\text { Spoon rice } \\
\text { blade }\end{array}$ & Half cylinders blade & Bowl blade \\
\hline 18 & 5784 & 15718 & 12045 & 14443 & 25512 \\
\hline 16 & 8497 & 14443 & 12045 & 15288 & 27175 \\
\hline 14 & 8826 & 16597 & 14029 & 17044 & 28888 \\
\hline
\end{tabular}

Table 12. Results of data processing efficiency of the electric generator

\begin{tabular}{|l|l|l|l|l|c|}
\hline \multirow{2}{*}{ Number of blades } & \multicolumn{2}{|l|}{ The efficiency of the generator, $\eta \mathrm{g}(\%)$} & \multicolumn{2}{|c|}{ Spoon rice } \\
\cline { 2 - 6 } & Flat blade & Curved blade & Half cylinders blade & Bowl blade \\
\hline 18 & 0002 & 0131 & 0300 & 0199 & 0661 \\
\hline 16 & 0001 & 0250 & 0332 & 0200 & 0714 \\
\hline 14 & 0224 & 0170 & 0405 & 0184 & 0736 \\
\hline
\end{tabular}

\section{DiscussionResearch result}

Results calculated from data in the table 6 to the table 12 is then used in the form of graphs, graphing aims to look at the phenomenon of the trending graph blade shape and the number of blades of the water turbine performance is done with the help of Microsoft Office Excel. The relationship between the shape of the blade and the number of blades on the performance of the turbine as shown in Figure 2 through Figure 8.

Based on the results of processing the data in Table 6 and Figure 2 is a graph based on the relationship of the blade shape and the number of turbine blades against tangential speed. In this study are given five variations of the blade is flat blade, curved blade, blade spoon, spoon half of the cylinder, the bowl blade and varied number of blades 18, 16, and 14 of the blade. When viewed from a variety of shapes blade, tangential velocity maximum occurs in the form of blade bowl, then the tangential velocity both occurred on the blade half cylinder, tangential velocity third occurred on the blade curvature, tangential velocity to four occurred in blade spoon, and the tangential velocity fifth or lowest occur in the flat of the blade. 
Shape Analysis of Blade AndNumber of Blade for Water Turbine Prototype Performance

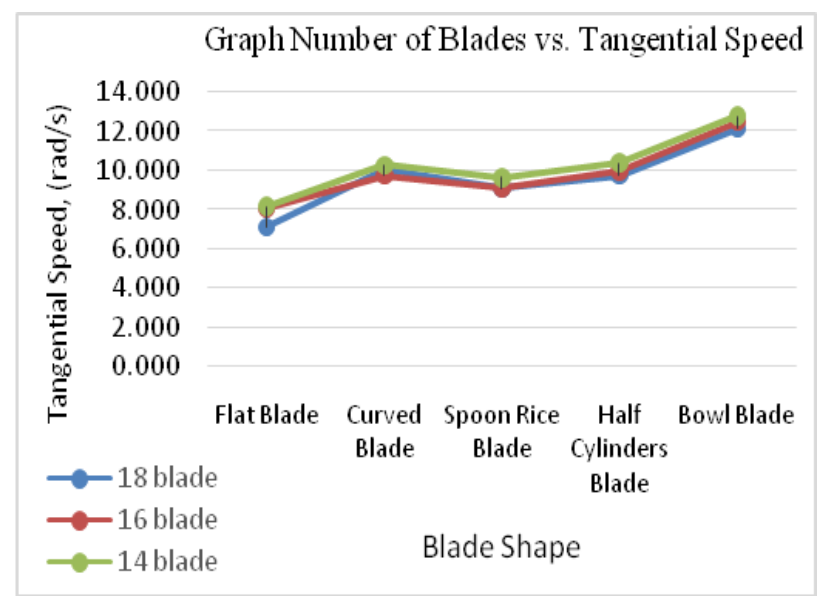

Figure 2. Graph Number of Bladesvs. Tangential Speed

The shape of the blade affects the tangential velocity, the more precise form of the turbine blade turbine wheel and a turbine wheel increases affect the resulting tangential force. To view the overall value of the tangential speed of the blade shape can be seen in Table 6. If seen from the variation of the blade under investigation, the maximum tangential velocity occurs in the number of blades 14 , then a second tangential velocity occurs in the number of blades 16 , and the third tangential velocity occurs in the number of 18 . the number of blades affect blade tangential velocity due to the number of blades 14 , the process of spraying the water through a turbine nozzle more exact / perfect on the blade compared with the number of blades 16 and 18. the maximum tangential speed of the blade occurs in the form of a bowl with blade number 14 with a value of $12769 \mathrm{rad} / \mathrm{s}$ and tangential velocity was lowest in the form of a flat blade with blade number 18 with a value of $7117 \mathrm{rad} / \mathrm{s}$.

Based on the results of processing the data in Table 7 and Figure 3 it can be concluded that the shape of the blade and the blade does not affect the amount of water hydraulic power, because in this study using a turbine flow rate and head are the same so there is no difference in the water hydraulic power value. Hydraulic power value in this study2.64 Watt.

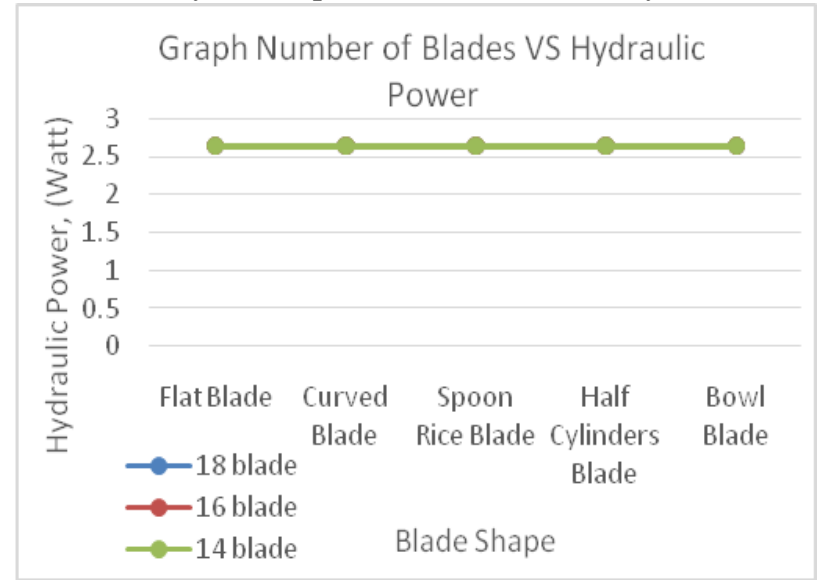

Figure 3. Graph Number of Blades VS Hydraulic Power

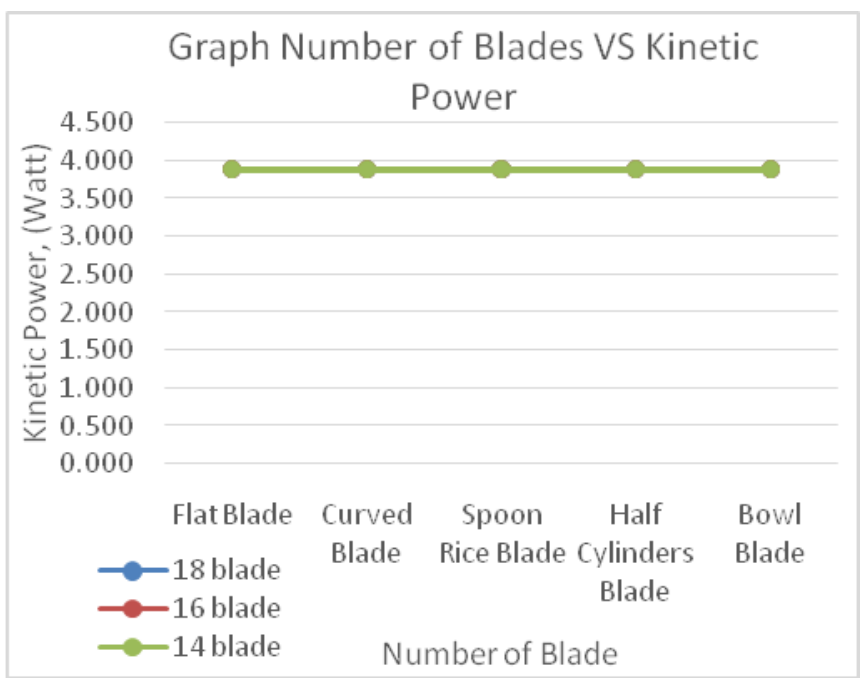

Figure 4. Graph Number of Blades vs. Kinetic Power

Based on the results of data processing in table 8 and figure 4 it can be concluded that the shape of the blade and the blade does not affect the amount of Kinetic power, because in this study using a one-size nozzle turbine (turbine nozzle cross-sectional area) so the water flow speed that comes out through the nozzle is the same. Kinetic power value in this study3,886 Watt.

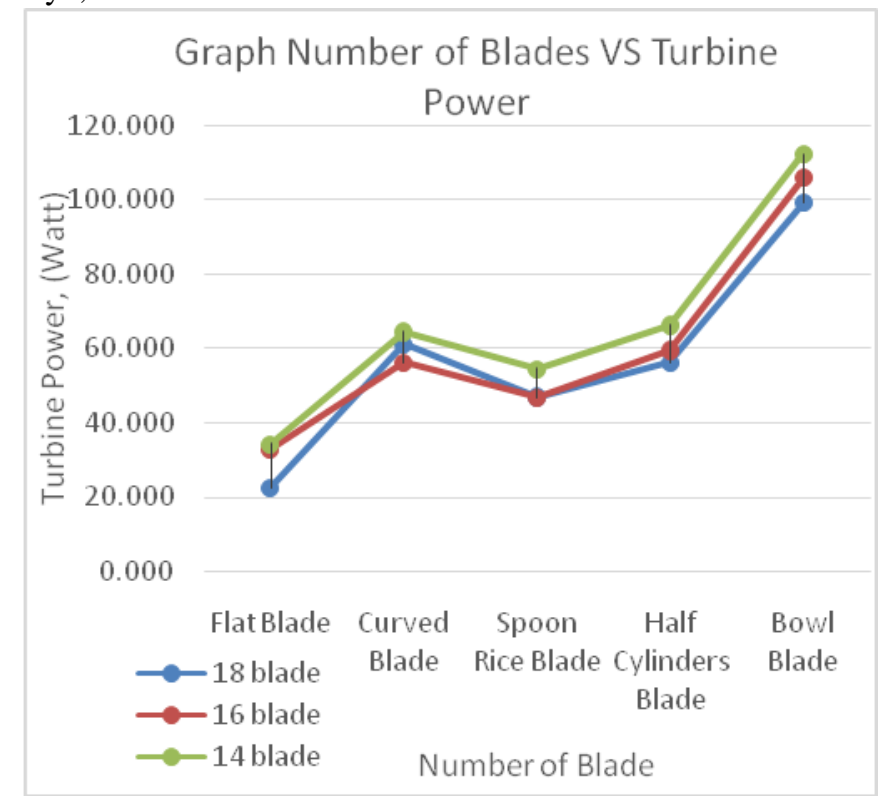

Figure 5. Graph Number of Blades vs.TurbinePower

Based on the results of processing the data in Table 9 and Figure 5 it can be seen that the shape of the blade and the blade affects the amount of power a turbine. In this study are given five variations of the blade is flat blade, curved blade, blade spoon, spoon half of the cylinder, the bowl blade and varied number of blades 18,16 , and 14 of the blade. Based on the figure 5 the turbine power maximum occurs in the form of blade bowl, then power the second turbine occurred on the blade half-cylinder, power third turbine occurred on the blade curvature, power turbines fourth occurred in blade spoon, and power turbine fifth lowest in the blade flat, The shape of the turbine blade influence and power turbine power influenced tangential velocity, whereas the tangential velocity have been affected by a turbine wheel, and a turbine wheel is very 
dependent on the mass flow rate and flow rate is influenced by the diameter of the turbine nozzle tip and nozzle size affect the speed of the flow coming out of the nozzle to affect the power of the turbine. the more precise form of the turbine blade turbine power increasing. To view the overall value of the tangential speed of the blade shape can be seen in Table 9. In terms of the number of blades studied variation, maximum turbine power occurs in the number of blades 14 with rated power turbine112 262 Watt, Then power the second turbine blade occurs in the number 16 with a value of 105603 Wattand third turbine power occurs in the number of blades 18 with a value of 99141 Watt, Number of blades affect tangential velocity due to the number of blades 14 , the process of spraying the water through a turbine nozzle more exact / perfect on the blade compared with the number of blades 16 and 18 .

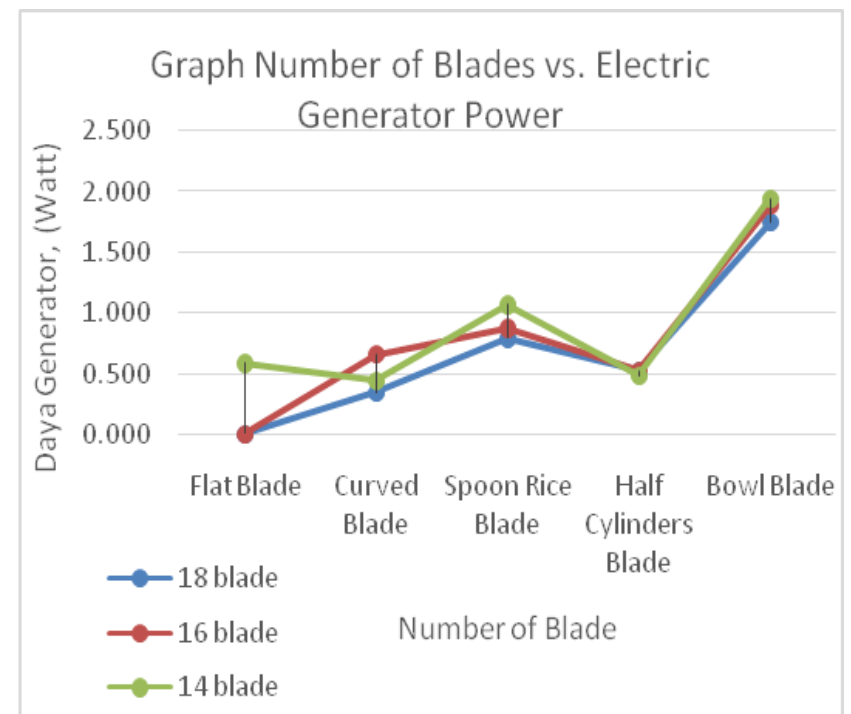

Figure 6. Graph Number of Blades vs.Electric Generator Power

Based on the results of processing the data in Table 10 and Figure 6 it can be seen that the shape of the blade and the blade affect the amount of electrical generators. In this study are given five variations of the blade is flat blade, curved blade, blade spoon, spoon half of the cylinder, the bowl blade and varied number of blades 18,16 , and 14 of the blade.

Based on Figure 6 that power an electric generator maximum occurs in the form of blade bowl, then power an electric generator both occur in blade spoon, power third turbine occurred on the blade half-cylinder, power turbines fourth occurred on the blade curvature, and power turbine fifth lowest in the flat blade. While the number of blades also affect the power of the electric generator, electric generator maximum power occurs in the number of blades 14 , the second electric generator power occurs in the number of blades 16 and the lowest electricity generator power occurs in the number of blades 18. The electric generator power is influenced by the electric voltage and electric current generated by the electric generator while the electric voltage and electric current is influenced by the rotation of electric generators and electric generator turbine rotation is affected by water. The more precise form of the turbine blade and the number of turbine blades then affects the electrical generator power. Electric generator maximum power occurs in the form of blade bowl and blade number 14 with a value of electric power generator for1,942 Watt. Whileelectric generator power was lowest in the form of a flat blade and blade number 18 with a value of electric power generator for 0.004 Watt.

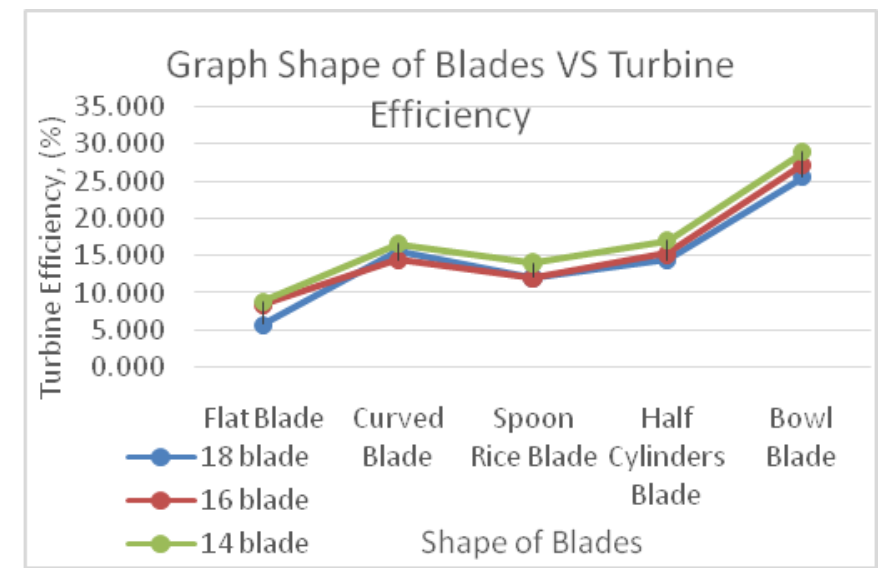

Figure 7. Graph Form Blade vs. Turbine Efficiency

Based on the results of processing the data in Table 11 and Figure 7 it can be seen that the shape of the blade and the number of blades affect the efficiency of the turbine. In this study are given five variations of the blade is flat blade, curved blade, blade spoon, spoon half of the cylinder, the bowl blade and varied number of blades 18, 16, and 14 of the blade. Based on the figure 7 the turbine efficiency maximum occurs in the form of blade bowl, then the efficiency of the second turbine occurred on the blade half-cylinder, turbine efficiency all three occurred in blade curved, turbine efficiency fourth occurred in blade spoon, and the efficiency of the turbine fifth lowest in the blade flat. While the number of blades also affects the efficiency of the turbine, the maximum turbine efficiency occurred in the number of blades 14 ,

Turbine efficiency is affected by the turbine power and kinetic power of water, the higher the turbine generated power the turbine efficiency increases, the more precise form of the turbine blade and the number of turbine blades then affect the efficiency of the turbine. The maximum turbine efficiency occurs in the form of blade bowl and blade number 14 with a value of turbine efficiency 28 888\%. Turbine efficiency was lowest in the form of a flat blade and blade number 18 with a value of turbine efficiency 5,784\%.

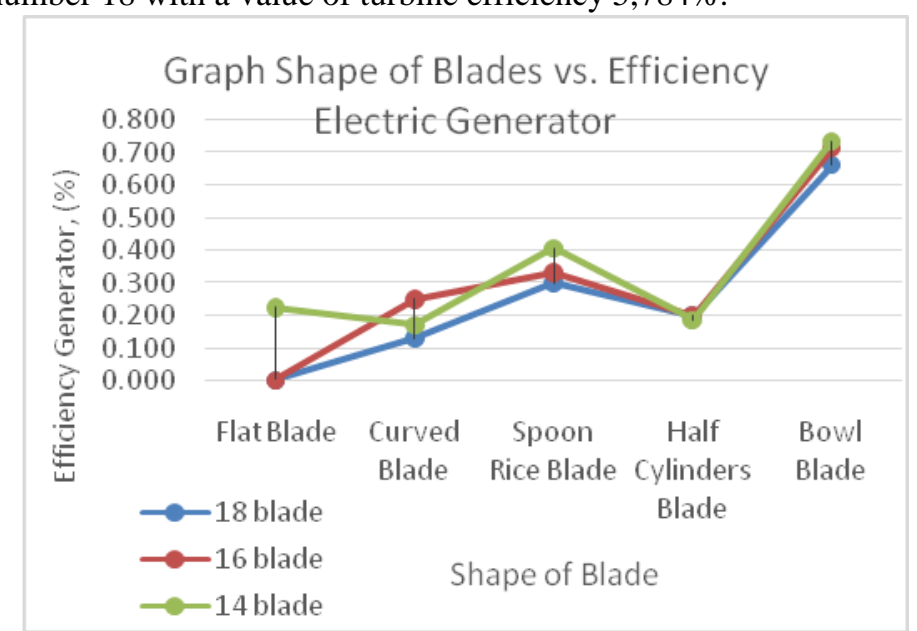

Figure 8. Graph Shape of Blades vs. Efficiency Electric Generator 
Based on the results of processing the data in Table 12 and Figure 8 it can be seen that the shape of the blade and the number of blades affect the efficiency of the electric generator. In this study are given five variations of the blade is flat blade, curved blade, blade spoon, spoon half of the cylinder, the bowl blade and varied number of blades 18,16 , and 14 of the blade. Based on the figure 8 the efficiency of the electric generator maximum occurs in the form of blade bowl, then the efficiency of the electric generator both occurred on the blade scoops of rice, the efficiency of the electric generator third occurred in a half-cylinder, the efficiency of the electric generator fourth occurred in the blade curvature, and efficiency of the electric generator fifth or lowest occur in the flat of the blade. While the number of blades also affects the efficiency of the electric generator,

The efficiency of the electric generator is influenced by the power generator and water hydraulic power, the higher the generated power generator then increasing efficiency electric generator, electric generator maximum efficiency occurs in the form of blade bowl and blade number 14, with the value of the electric generator $0736 \%$. The efficiency of the electric generator was lowest in the form of a flat blade and blade number 18 with a value of turbine efficiency $0.002 \%$.

\section{CONCLUSION}

The results showed the influence of the shape of the blade and the number of prototype turbine blade on the performance of water, so it can be concluded that:

1. The maximum tangential velocity occurs in the form of blade bowl with blade number 14 with a value of $12769 \mathrm{rad} / \mathrm{s}$ and tangential velocity was lowest in the form of a flat blade with blade number 18 with a value of $7117 \mathrm{rad} / \mathrm{s}$.

2. Hydraulic power value in this study $2.64 \mathrm{Watt}$.

3. Kinetic power value in this study 3,886 Watt.

4. The maximum turbine power occurs in the form of blade bowl and blade number 14 with rated power turbine 112262 Watt, Then the power turbine blade was lowest in the number 18 with a value of 99141 Watt.

5. Electric generator maximum power occurs in the form of blade bowl and blade number 14 with a value of electric power generator for 1,942 Watt. Whileelectric generator power was lowest in the form of a flat blade and blade number 18 with a value of electric power generator for 0004 Watt

6. The maximum turbine efficiency occurs in the form of blade bowl and blade number 14 with a value of turbine efficiency $28888 \%$. Turbine efficiency was lowest in the form of a flat blade and blade number 18 with a value of turbine efficiency $5,784 \%$.

7. The efficiency of the electric generator maximum occurs in the form of blade bowl and blade number 14 , with the value of the electric generator $0736 \%$. The efficiency of the electric generator was lowest in the form of a flat blade and blade number 18 with a value of turbine efficiency $0.002 \%$.

\section{REFERENCES}

[1] Arismunandar., W. (2004). "First mover turbine",third edition of ITB, Bandung.

[2] Hamidi. Supandi. And Rohermanto, A, (2006). "Construction of the Pelton turbine Model Mini For Media Simulation / Practical Course Fluid Mechanics and Energy Conversion". Scientific Journal SemestaTeknika, Department of Mechanical Engineering Polytechnic Pontianak.

[3] Prasad, G. and Dharma, U. S, (2012). "Influence of Flow Rate Changes Against Pressure and Flow Type Happens At Practice Test Equipment Fluid Mechanics". Turbo Journal. Study Program Faculty of Engineering, University of Muhammadiyah Metro. Lampung.

[4] Susatyo, A. and Judge, L (2003). "The design of the turbine pelton".ProsidingNational Seminar dates 29 to 30 June, informatics research center - LIPI. duo

[5] Yani. A Mihdar and Erianto. R (2016). "The effect of variations on the Performance of Water turbine blade kinetic" (For Power Plant Rural)". Turbo Journal. Department of Mechanical Engineering, Faculty of Engineering, University of Muhammadiyah Metro - Lampung.

[6] Thobari. A, Mustaqim, and Wibowo H, (2013). "Analysis of the Effect of Angle Exit Pelton turbine blade AgainstRound".Scientific journal Faculty of Engineering, University of PancasaktiTegal.

[7] Yani. A, (2017). "The design of practical tools to test water turbine blade shape of the torque and power produced by the turbine". Turbo Journal. Department of Mechanical Engineering, Faculty of Engineering, University of Muhammadiyah Metro- Lampung.

[8] Rosmiati, \&Yani. A, (2017) "The Influence of the nozzle diameter variation of the torque and power of water turbines". Turbo Journal. Department of Mechanical Engineering, Faculty of Engineering, University of Muhammadiyah Metro - Lampung. 